\title{
Hereditary distal muscular atrophy with vocal cord paralysis and sensorineural hearing loss: a dominant form of spinal muscular atrophy?
}

E BOLTSHAUSER*, W LANG $\dagger$, T SPILLMANN

From the Departments of ${ }^{*}$ Pediatrics, †Pathology, and $\ddagger$ Otorhinolaryngology, University of Zürich, Switzerland.

SUMmARY In 1980 Young and Harper described a family with an unusual form of distal spinal muscular atrophy associated with vocal cord paralysis. We report a family with three similarly affected subjects. Progressive sensorineural hearing loss was an additional feature in our patients. Electrophysiological and histological investigations did not exclude an involvement of sensory neurones. Whether the classification of this dominant disorder with the spinal muscular atrophies is justified will depend on additional studies in further families.

Young and Harper ${ }^{1}$ described a large kindred with a particular form of spinal muscular atrophy, inherited as an autosomal dominant trait. Vocal cord paralysis was an additional characteristic symptom, but impaired hearing was not a feature. Serratrice et al reported a similar patient with a somewhat later onset. His sister (not examined) also was said to be similarly affected. There is no information available on their parents.

Received for publication 9 July 1987.

Revised version accepted for publication 9 June 1988.
We are not aware of reports of any additional cases. We report here a family with three similarly affected members who, in addition, have marked hearing impairment.

\section{Case reports}

The family pedigree is shown in fig 1 . The affected subjects are described briefly in the order in which they were seen. Each affected patient had the following features: distal muscular atrophy, more

I

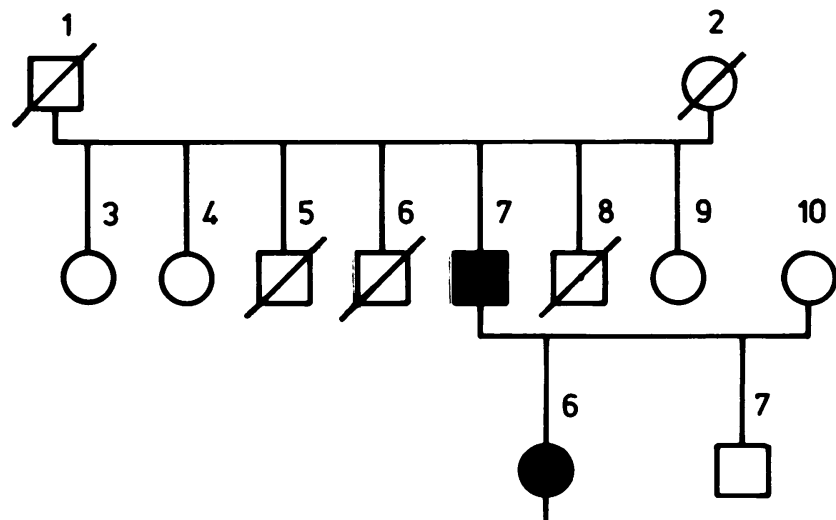

IV

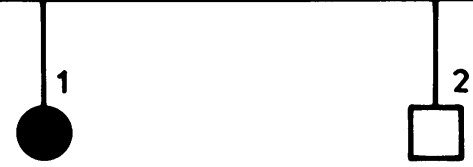

FIG 1 The family pedigree. Shaded symbols indicate affected subjects. 
pronounced in the upper limbs; muscle weakness, in the later stages also affecting the proximal muscles; tendon areflexia; no thickening of the peripheral nerves; intact sensation; normal intelligence.

IV. 1

This girl was referred at the age of 13 years for evaluation of an unusual gait and impaired exercise tolerance. In addition to the above mentioned findings she had marked scapular winging. In the following three years her muscle weakness increased considerably and she has developed thoracic scoliosis. Impaired hearing was only realised on specific testing. She was known to have a marked stridor from about six months of age. At the age of 10 years, before the diagnosis of her neurological illness, a unilateral arytenoidectomy was performed elsewhere.

\section{6}

This 35 year old woman was investigated after a diagnosis of spinal muscular atrophy was considered in her daughter. She had a history of weakness and wasting of the hand muscles since childhood. Vocal cord changes were only recognised on laryngoscopy; however, she had been aware of impaired hearing affecting higher frequencies for several years. Her condition has remained stable for many years.

\section{7}

This 65 year old man noticed weakness and wasting of the small hand muscles during adolescence. Lower limb involvement became evident in his fifties, when he also required bilateral hearing aids. He had a hoarse voice from approximately 40 years of age.
Neurological, audiological, and laryngoscopic $\overrightarrow{\vec{F}}$ examinations were normal in family members III. $4-\frac{7}{0}$ and IV.2. Additional family members were not available for examination. By history no other affected subjects were known.

\section{Special investigations}

ELECTROPHYSIOLOGICAL STUDIES

These findings are summarised in table 1 . Electro- $\vec{\omega}$ myography performed in subjects III.6 and IV.1 showed reduced recruitment pattern and large polyphasic units of long duration in the small hand $\stackrel{\sim}{\sigma}$ muscles.

SERUM CREATINE KINASE

The following serum CK values were found. IV.1: 윽 200 to $680 \mathrm{U} / 1$ (repeated examinations), III.6: 160 to $370 \mathrm{U} / 1$ (repeated examinations), II.7: $350 \mathrm{U} / 1$. T (Normal values $\leqslant 210 \mathrm{U} / 1$.)

\section{NERVE AND MUSCLE BIOPSIES}

These were performed in III.6 at the age of 39 years $\vec{\varphi}$ during elective surgery. A muscle biopsy from the right quadriceps showed moderate abnormalities with some variation of fibre size and fibre type grouping in the myofibrillary ATPase reaction. There was no evidence of fibre degeneration or regeneration. The changes in the right gastrocnemius $\frac{}{\Phi}$ muscle were marked: longstanding denervation $\stackrel{\varrho}{\rightarrow}$ atrophy of motor unit type with fibre atrophy involving whole fascicles, areas of hypertrophic fibres, and slight increased endomysial connective tissue. Thus, the myopathological changes were considerably more pronounced distally.

The right sural nerve biopsy showed norma

TABLE 1 Electrophysiological studies.

\begin{tabular}{|c|c|c|c|c|c|c|c|}
\hline \multirow[t]{3}{*}{ Patient } & \multirow{3}{*}{$\begin{array}{l}\text { Age } \\
(y)\end{array}$} & \multirow[t]{3}{*}{ Nerve studied } & \multicolumn{5}{|c|}{ Nerve conduction } \\
\hline & & & \multicolumn{3}{|l|}{ Motor } & \multicolumn{2}{|l|}{ Sensory* } \\
\hline & & & $\begin{array}{l}\text { Velocity } \\
(\mathrm{m} / \mathrm{s})\end{array}$ & $\begin{array}{l}\text { Distal latency } \\
\text { (ms) }\end{array}$ & $\begin{array}{l}\text { Amplitude } \\
(\mathrm{mV})\end{array}$ & $\begin{array}{l}\text { Velocity } \\
(\mathrm{m} / \mathrm{s})\end{array}$ & $\begin{array}{l}\text { Amplitude } \\
(\mu V)\end{array}$ \\
\hline \multirow[t]{2}{*}{ IV.1 } & \multirow[t]{2}{*}{13} & $\begin{array}{l}\text { Right median } \\
\text { Right tibial } \\
\text { Right peroneal }\end{array}$ & $\begin{array}{l}50 \\
45 \\
\text { ND }\end{array}$ & $\begin{array}{l}3.5 \\
5.2\end{array}$ & $\begin{array}{r}7 \\
12\end{array}$ & 55 & 10 \\
\hline & & Right radial & & & & 46 & 15 \\
\hline \multirow[t]{3}{*}{ III.6 } & \multirow[t]{3}{*}{35} & $\begin{array}{l}\text { Right median } \\
\text { Right ulnar }\end{array}$ & 61 & $3 \cdot 3$ & 13 & $\begin{array}{l}52 \\
49\end{array}$ & $\begin{array}{l}10 \\
10\end{array}$ \\
\hline & & $\begin{array}{l}\text { Right radial } \\
\text { Right tibial } \\
\text { Right peroneal }\end{array}$ & $\begin{array}{l}49 \\
52\end{array}$ & $\begin{array}{l}4.4 \\
5.4\end{array}$ & 10 & 62 & 17 \\
\hline & & Right sural & & & & \multirow[t]{2}{*}{54} & \multirow[t]{2}{*}{8} \\
\hline II.7 & 65 & $\begin{array}{l}\text { Right median } \\
\text { Right tibial }\end{array}$ & $\begin{array}{l}50 \\
37\end{array}$ & $\begin{array}{l}4.9 \\
5.5\end{array}$ & $\begin{array}{l}4 \\
0.4\end{array}$ & & \\
\hline
\end{tabular}

ND= not done.

*The values for sensory nerve conduction velocities represent antidromic recordings. With our laboratory setting we have the following lower normal limits for sensory action potential amplitudes: sural nerve $\geqslant 10 \mu \mathrm{V}$, other nerves $>15 \mu \mathrm{V}$. 


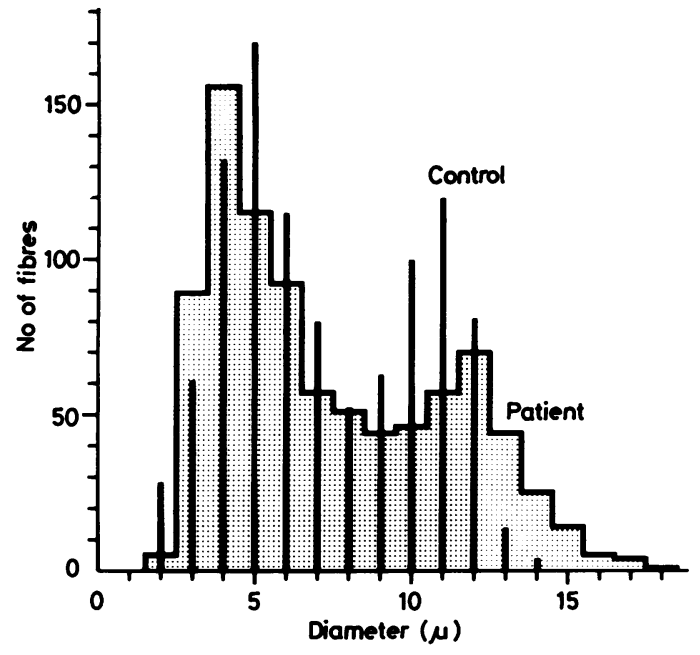

FIG 2 Myelinated fibre size frequency histogram from the sural nerve of case III.6. The size distribution (based on 875 fibres measured) is bimodal, with maxima at 4 and at 12 $\mu \mathrm{m}$. This is considered normal. The lines correspond to control values (mean of six cases) of Ochoa and Mair. ${ }^{3}$

TABLE 2 Vocal cord changes.

\begin{tabular}{llll}
\hline Patient & $\begin{array}{l}\text { Age } \\
(y)\end{array}$ & $\begin{array}{l}\text { Clinical } \\
\text { signs }\end{array}$ & Laryngoscopy \\
\hline IV.1 & 13 & Stridor & $\begin{array}{l}\text { Abduction palsy right cord } \\
\text { Arytenoidectomy performed left cord } \\
\text { (aged 10 y) } \\
\text { Abduction palsy left cord } \\
\text { Abduction palsy left cord }\end{array}$ \\
III.6 & 35 & - & Hoarse voice \\
II.7 & 65 &
\end{tabular}

fascicular architecture without endoneurial fibrosis. Macrophages were not present. Electron microscopy showed no abnormal accumulation of neurofilaments or other organelles. No Schwann cells unassociated with axons were present, nor were regeneration clusters detected. Myelinated fibre density was $3026 / \mathrm{mm}^{2}$. The usual normal range is $7700 / \mathrm{mm}^{2}$ (SD 1200). A myelinated fibre size frequency histogram is shown in fig 2 . This is comparable to the controls reported by Ochoa and Mair. ${ }^{3}$

\section{LA R Y N GOS COPY}

The findings are described in table 2. Otoscopic inspection was unremarkable in all subjects.

\section{PURE TONE AUDIOMETRY}

This is shown in fig 3.

\section{ADDITIONAL AUDIOLOGICAL TESTS}

Tympanometry and brain stem audiometry was performed in subjects IV.1 and III.6. In both, the cochlear location of the hearing impairment was confirmed by normal latencies and transmission times $(4 \cdot 1$ and $4.2 \mathrm{msec}$ respectively at $80 \mathrm{~dB} \mathrm{nHL}$, unfiltered click) for brainstem waves $I$ and V. Stapedial reflexes were normal in subject III.6, but in subject IV.1 a crossed reflex decay phenomenon was found upon stimulation of the left ear at frequencies of 500 to $2000 \mathrm{~Hz}$. Therefore, a slight neural component in addition to a primarily cochlear involvement cannot be excluded.
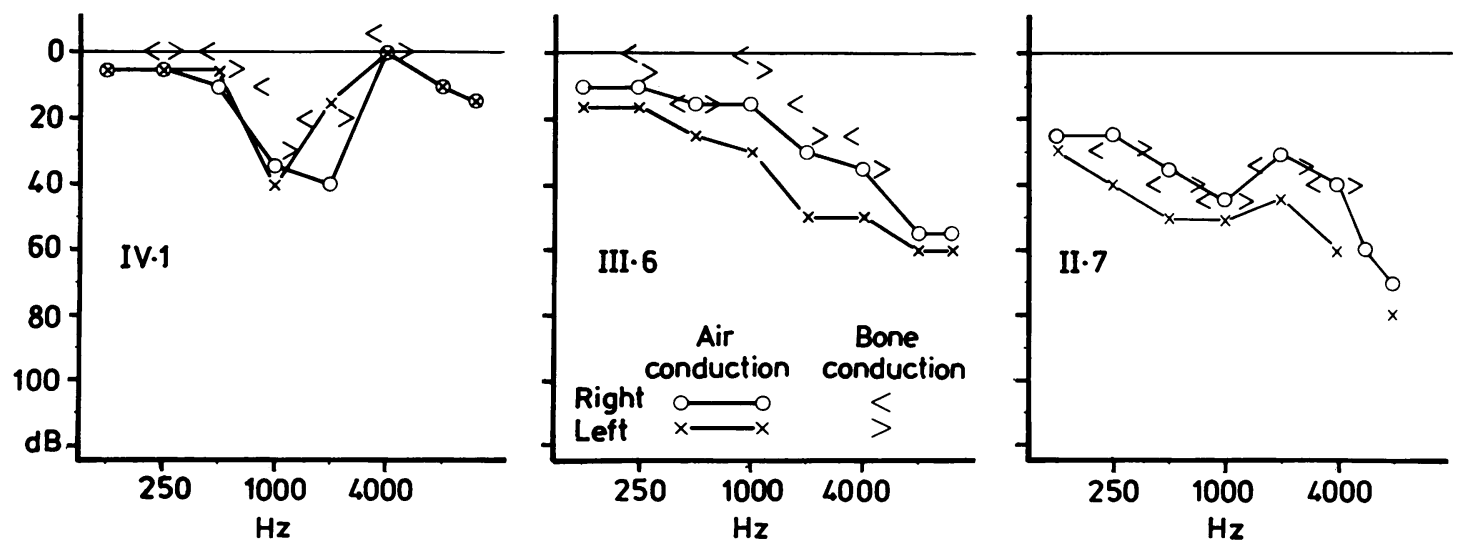

FIG 3 Pure tone audiograms. Hearing losses of subjects IV.1 and III.6 were exclusively sensorineural. In subject II.7, an additional conductive component cannot be excluded. Age influences the high tone sensitivity (subjects III.6 and II.7 had pronounced left loss centred at frequencies 2000 to $8000 \mathrm{~Hz}$ and 4000 and $8000 \mathrm{~Hz}$, respectively). In the youngest subject (IV.1), hearing loss was found between 1000 and $2000 \mathrm{~Hz}$ with normal perception at all other frequencies. Therefore, it may be assumed that the hearing loss started at the middle frequencies during early childhood with later progression to involve higher frequencies. 


\section{Discussion}

The symptoms observed in our patients were very similar to those described by Young and Harper. ${ }^{1}$ The onset and course, as well as the distribution of muscle wasting and atrophy, was identical. Young and Harper could not confirm the diagnosis of spinal muscular atrophy by muscle and nerve biopsy and they did not report sensory conduction studies. In our family the diagnosis of a spinal muscular atrophy was initially considered, in view of the normal sensory testing, normal motor nerve conduction, electromyographic findings, and muscle biopsies performed in one affected subject. The raised CK values were also compatible with the diagnosis of spinal muscular atrophy since this finding has been described in other forms. ${ }^{4}$ The moderate reduction of motor nerve conduction velocity in the lower limbs in subject II.7 could probably be explained by a loss of large motor neurones.

However, the sensory nerve conduction studies (performed in subjects IV.1 and III.6 but not in the oldest affected patient) were not unequivocally normal: the values for the velocities were all within the normal range for our laboratory, but the sensory action potential amplitudes were reduced in the lower (sural nerve) and upper limbs (median and ulnar nerves). This could be interpreted as a moderate additional sensory involvement, possibly from a loss of dorsal root ganglion cells. In addition sural nerve myelinated fibre density $\left(3026 / \mathrm{mm}^{2}\right)$ was clearly abnormal (normal 7700, SD 1200).

We found this result difficult to interpret. The myelinated fibre size histogram was comparable to controls. This could still be explained if the loss was uniform for fibre size. However, a marked reduction of large myelinated fibres was unlikely since this would result in reduced sensory nerve conduction velocities as well.

In view of the possibility that sensory neurones are involved, a classification of this disorder as a form of spinal muscular atrophy is only provisional and will depend on additional studies in further families or patients.

Our patients had laryngeal involvement identical to the patients described by Young and Harper. ${ }^{1}$ However, our subjects also had progressive sensorineural hearing impairment. Since this abnormality was clinically obvious in the older two patients, it seems very unlikely that sensorineural hearing loss was missed by Young and Harper. Recently, sensorineural hearing loss was reported in patients with facioscapulohumeral muscular dystrophy, ${ }^{5-7}$ a con- dition which is very different clinically from the $\overrightarrow{\vec{S}}$ findings in our patients.

The clinical features in this family were unique and clearly different from other forms of distal $\frac{\bar{\omega}}{\bar{\omega}}$ spinal muscular atrophy ${ }^{8-11}$ as well as from reports $\widehat{\Phi}$ of familial laryngeal disorders. ${ }^{12-15}$

We hypothesise that the clinical findings are most ${ }^{\text {के }}$ likely caused by a pleiotropic effect of a single $\vec{O}$ mutant gene. Further reports of similar families may $\overrightarrow{\vec{\omega}}$ determine whether this family and the pedigree $\mathcal{O}^{\omega}$ reported by Young and Harper ${ }^{1}$ represent variants of the same disease entity with variable hearing impairment or different disorders.

This study was presented in part at the Annual $\stackrel{\text { i }}{\rightarrow}$ Meeting of the Swiss Neurological Society, 4 May $\stackrel{\circ}{\circ}$ 1984, Lugano.

\section{References}

1 Young ID, Harper PS. Hereditary distal spinal muscular $\frac{\mathbb{D}}{O}$ atrophy with vocal cord paralysis. J Neurol Neurosurg Psychiatry 1980;43:413-8.

2 Serratrice G, Pellissier JF, Gastaut JL, Desnuelle C. Amyotrophie spinale chronique avec paralysie des cordes vocales: $\vec{\vartheta}$ syndrome de Young et Harper. Rev Neurol (Paris) 1984;140: 657-8.

${ }^{3}$ Ochoa J, Mair WGP. The normal sural nerve in man. I. $\square$ Ultrastructure and number of fibers and cells. Acta Neuropathol (Berl) 1969;13:197-216.

4 Ringel SP, Lava NS, Treihaft MM, Lubs ML, Lubs HA. Late- $\bar{\partial}$ onset X-linked recessive spinal and bulbar muscular atrophy. 을 Muscle Nerve 1978;1:297-307.

5 Lamprecht A, Voit T, Lenard HG, Göbel HH. Hörstörungen bei Muskeldystrophie. Sprache Stimme Gehör 1986;10:47-51.

6 Taylor DA, Carroll JE, Smith ME, Johnson MO, Johnston GP, $\frac{\text {, }}{3}$ Brooke MH. Facioscapulohumeral dystrophy associated with $\vec{\partial}$ hearing loss and coats syndrome. Ann Neurol 1982;12:395-8.

7 Voit T, Lamprecht A, Lenard HG, Goebel HH. Hearing loss in facioscapulohumeral dystrophy. Eur J Pediatr 1986;145:280-5.

8 Pearn J. Classification of spinal muscular atrophies. Lancet 1980;i:919-21.

9 Gomez MR. Motor neuron diseases in children. In: Engel AG, Banker BQ, eds. Myology. New York: McGraw-Hill, 1986: 1993-2012.

10 Pearn J, Hudgson P. Distal spinal muscular atrophy. J Neurol Sci 1979;43:183-91.

11 Harding AE, Thomas PK. Hereditary distal spinal muscular atrophy. J Neurol Sci 1980;45:337-48.

12 Plott D. Congenital laryngeal-abductor paralysis due to 을. nucleus ambiguus dysgenesis in three brothers. $N$ Engl J Med $N$ 1964;271:593-7.

13 Watters GV, Fitch N. Familial laryngeal abductor paralysis and $N$ psychomotor retardation. Clin Genet 1973;4:429-33.

14 Mace M, Williamson E, Worgan D. Autosomal dominantly inherited adductor laryngeal paralysis-a new syndrome with a suggestion of linkage to HLA. Clin Genet 1978;14:256-70.

15 Cunningham MJ, Eavey RD, Shannon DC. Familial vocal cord dysfunction. Pediatrics 1985;76:750-3.

Correspondence and requests for reprints to $\mathrm{Dr} \mathrm{E}$ Boltshauser, Children's Hospital, Steinwiesstrasse 75, CH-8032 Zürich, Switzerland. 